\title{
BETWEEN DOMESTIC AND GLOBAL POLITICS: THE DETERMINANTS OF ERITREA'S SUCCESSFUL SECESSION
}

\author{
Albano Agostinho Troco ${ }^{1}$
}

\section{Introduction}

Secessionist conflicts are not a novel occurrence in the African continent. Since the dawn of independence in the Ig 60 s, a number of countries have been home to rebellions involving marginalized communities or ethno-linguistic groups demanding territorial separation from existing states with the goal to create new independent states. The list is long and includes territorial units in countries such as Angola (Cabinda), Comoros (Anjouan and Mohedi), The Democratic Republic of Congo (Katanga, South Kassai) Ethiopia (Eritrea, Ogaden, and Oromia, Afar), Mali (Tuaregs), Niger (Tuaregs), Nigeria (Biafra, Niger Delta), Senegal (Casamance), Somalia (Somaliland) and Sudan (South Sudan) only to mention a few amongst others.

Despite the high incidence of secessionist conflicts on the continent, only two cases have succeeded in the establishment of new states: Eritrea in 1993 and South Sudan in 20II. This study advances a number of factors that can help to make sense of Eritrea's formal withdrawal from Ethiopia on 24 May I993. This event represents an extraordinary development in postcolonial Africa because it was the first time that a territorial unit within an existing African state successfully separated to become a state. ${ }^{2}$ In addition, Eritrea's secessionist struggle and independence took place within a conti-

I Department of Political Studies, University of the Witwatersrand, Johannesburg, South Africa. E-mail: albanotroco@gmail.com

2 Previous widely reported secessionist attempts in Katanga (I960) and Biafra (I967) failed as they were effectively crushed by the military of their respective parent-state, the Republic of Congo and the Federal Republic of Nigeria. 
nental framework that was particularly hostile to the emergence of new states outside the colonial context (Troco 2018, 55) .

From this perspective, this study contributes to debates on the determinants of successful secessions with particular reference to the African continent. Its central argument is that the successful outcome of the secessionist struggle in Eritrea is the result of a tight combination of domestic and external factors. These include Eritrea's historical and legal claims for territorial self-determination, the Dergue's policies of alienation, the effectiveness of the Eritrean Peoples Liberation Front's strategies (EPLF), the collapse of the Soviet Union and the end of the Cold War, and the supportive role of the United States of America.

The discussion proceeds in the following manner: the first section provides a theoretical overview of secession; the second section reflects on the root-causes of secessionist demands in Africa; the third section looks at the political geography and history of Eritrea; the fourth section describes the dynamics of secessionist alienation and armed resistance in Eritrea; while the final section expounds on the determinants of Eritrea's successful secession.

\section{Understanding Secession}

Secession is a contested concept (Doyle 20I0:I). Like most concepts in the social sciences, there is little consensus amongst scholars on the definition of secession (Pavikovic and Radan 2007:4). Anderson (2013:344), for instance, views secession as any case of state formation out of an established sovereign state. From this perspective, the vast majority of former colonies in Africa and Asia would be considered cases of secession. Kohen (2006:I) and Pavikovic and Radan (2007:I) restrict secession to cases of states formed outside the colonial context, while Bartkus (1999) highlights the role of recognition by other states as an essential criterion for statehood.

At the center of the concept of secession is the notion of separation, emanating from the etymology of the word, the Latin verb secede, which means, 'to go apart' (Pavikovic and Radan, 2007:5). In this regard, Anderson (2013:345) clarifies that 'secession is synonymous with moving apart or withdrawing'. This notion is clearly reflected in the definition espoused in this study. Accordingly,

3 The policies of the Organization of African Union (OAU) and its successor the African Union (AU) support and uphold the inviolable character of the inherited colonial borders of African states. 
secession is 'the creation of a new independent state entity through the separation of part of the territory and population of an existing state' (Kohen 2006:I).

However, it should be noted that secession is not an instant fact. Scholars have created a number of theories to explain when and why secessions or attempts at secession occur. These theories are categorized into three distinct groups: I) explanatory theories, which are concerned with the social, political and economic factors leading to or causing secession ${ }^{4}$; 2) normative theories, which focus on the moral and ethical justifications for secession;; and 3) legal theories, which confront the rights of people for self-determination and the preservation of the territorial integrity of states outlined on a variety of domestic and international legal documents ${ }^{6}$.

Although theoretically relevant, normative and legal approaches to secession limit the analysis of secessionist conflicts to the level of ideas. A useful theory of secession must transcend the realm of ideas and engage germane structural factors such as the social, political and economic context in which secessions or attempts at secession take place. As explained by Keller $(2007,3)$, 'only in this way theories can provide the roadmap for understanding and even resolving intrastate conflicts that revolve around demands by certain groups to separate'.

Explanatory theories of secession view the phenomenon. First and foremost, as a process directed towards the attainment of independent statehood, often implying in a 'complex series of claims and decisions, negotiations and/or struggle, which may - or may not - lead to the creation of a new state' (Kohen 2006:I4). Along the same lines, Premdas (2013:4) comments that 'secession may be conceived analytically as constituted of steps and stages, cumulative and precipitating causes, periodically displaying patterns of accommodation and intransigence'.

In general, secessionist movements and conflicts arise when sub -state ethno-cultural communities, frustrated in their quest for recognition and resources, challenge the state and its territorial definition through the pursuit of independent statehood. Since territorial fragmentation of the state is a threat against the very definition of the state, central governments often attempt to militarily subdue separatist groups leading to the inception of

4 Wood's (I980) comparative analytical model on secession and Butt's (20I7) state strategy theory fall within this category.

5 Buchanan's (I99I) Secession: the morality of political divorce from Fort Sumter to Lithuania and Quebec illustrates theories in this category.

6 An example of such an approach is Dersso's (20I2) International Law and the Self-determination of South Sudan. 
civil wars (Pavikovic and Radan 20II:I). These armed conflicts tend to be 'prolonged, punishing, and prohibitively costly and are fought with fanatical intensity and uncompromising stubbornness involving high civilian casualties' (Beary 2008:I).

As in most conflicts, foreign states, with their own interests and agenda, often join the fighting parties adding fuel to the sustenance of the struggle (Premdas 2013:5). This turn external factors, in particular geopolitical considerations, a critical variable in accounting for the development and outcome of secessionist conflicts. For instance, Butt $(2017,2)$ presents an interesting account about how 'secession negatively alters the balance of power, with respect to both the secessionist ethnic group and existing state rivals'. Horowitz (1985:230) explains this view clearly in his observation that, 'while the emergence of a secessionist movement is determined mainly by domestic politics - the relations of groups and regions within the state; the success of secessionist struggle is determined largely by international politics, the balance of interests and forces that extend beyond the state'.

The final stage in the process of achieving statehood is international recognition. As explained by Wood (I980:I33), a “"successful”' secession is not complete until it has become institutionalized in a new government, legitimate at home and recognized abroad'. Pavikovic and Radan (2007:I0) hold the same view, elucidating that once a territory breaks off from its parent state, recognition by other states completes the process of achieving statehood. Put differently, an entity is treated as a state only if the outside world recognizes it to be one (Sterio 2009:8), a process that is normally informed by political considerations (Ker-Lindsay 20I2:7).

\section{The Root-Causes of Secessionist Conflicts in Africa}

As outlined in a previous study, the origins of secessionist conflicts in post-colonial Africa are to be found essentially in the specificity of interstate boundaries and issues of governance (Troco 2018, 58-59).

Most interstate boundaries in Africa were demarcated at the Berlin conference in I884 and have remained virtually unchanged since then. In the words of a prominent Africanist scholar, these boundaries are known to be 'artificial and arbitrary on the basis of the fact that they do not respond to what people believe to be rational demographic, ethnographic, and topographic boundaries' (Herbst I989:693), and for 'their propensity for bringing together peoples that historically lived under different, if not inimical systems' 
(Engelbert et al. 2001:1093). However, the nationalist elite agreed to maintain the inherited colonial borders, transforming them into international boundaries between the emerging post-independent states (Hughes 2004:834). Since then, respect for the sacrosanct character of African borders became the official policy of the OAU and later reaffirmed by its successor the AU.

Another issue at the core of secessionist conflicts in post-colonial Africa relates to poor governance. Indeed, dynamics of marginalization lead groups to challenge the state (Ylonen 20I3:I3I). Ndulo (20I3) reports that, 'failure of governance leads minority groups to believe that they are not included in running the affairs of the state'. According to Katz (I995:I83) 'this frustration often leads to mobilization under ethnic or territory-based identity with the belief that the group's rights would be adequately protected in a self-governed territory'. Bamfo (20I2:37) subscribes to this view indicating that ideological and policy differences between a region or ethnic group and the central government might lead to the emergence of separatist sentiment which might or might not develop into a secessionist war.

\section{Political Geography and History of Eritrea}

Secession presupposes the existence of a territory inhabited by a potentially secessionist population. Hence, before proceeding with the examination of the determinants of Eritrea's successful secession, it is crucial to start with an overview of the region's geographical location, its people and their history.

Accordingly, Eritrea 7 is situated along the west coast of the Red Sea, north of the Horn of Africa. The country is relatively small compared to other African states, bordering the Sudan on the north and northwest, Ethiopia on the south and Djibouti on the southeast. Although the country has a population of approximately 5.2 million, Eritrea has been described as home to a 'mosaic of diverse communities' (Sherman I980, 3). This includes the Afar, Bilen, Hedareb, Kunama, Nara, Rashaida, Saho, Tigre and Tigrinya. The last two constitute the major ethno-linguistic groups in the country. Tigre-speaking Eritreans are mostly Muslims and agro-pastoralists, inhabiting the eastern and western lowlands, while Tigrinya-speaking Eritreans are generally Christians and share ethnic ties with Tigrinya-speaking communities in Ethiopia (Mussie 20II, I8).

7 The Italians named the territory in I890 after the Roman Erythraeum Mare, literally meaning 'red sea' (Fegley I995: xv). 


\section{Political Map of Eritrea}

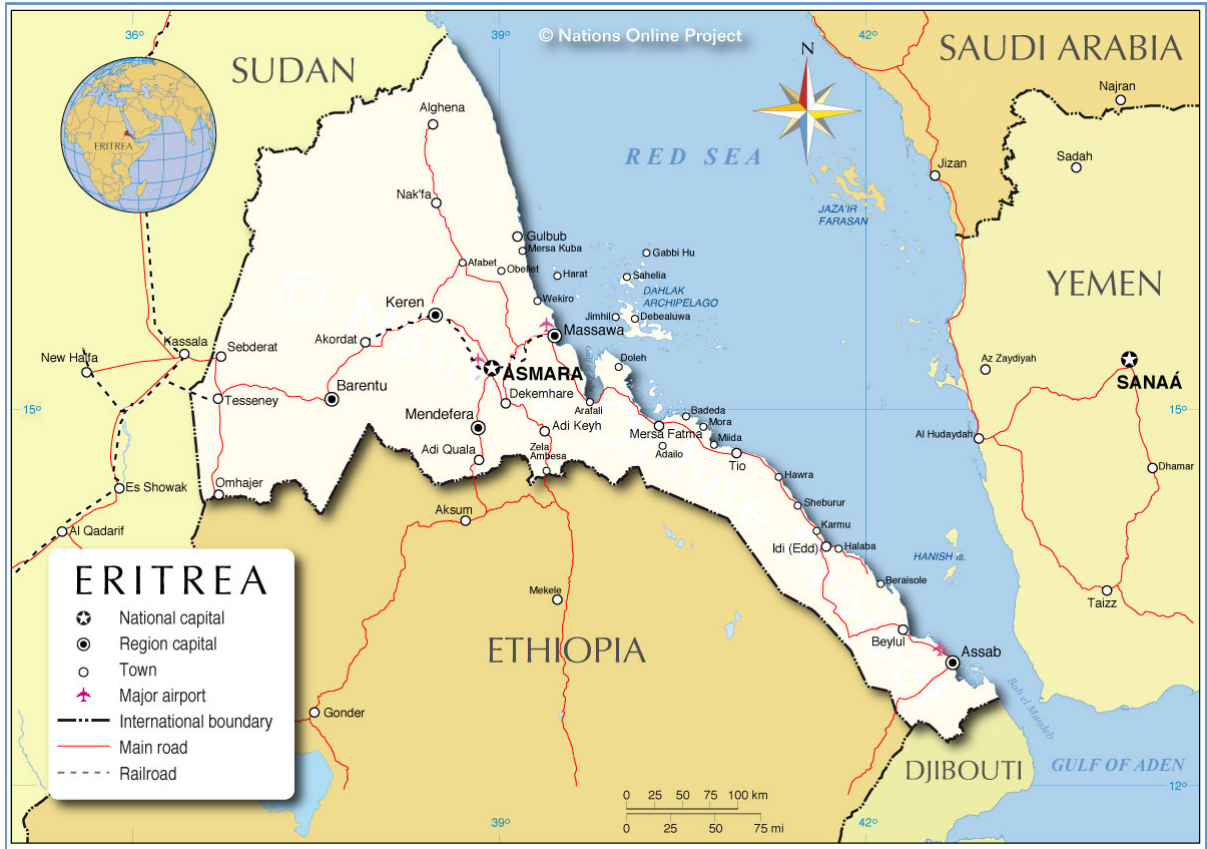

Source: https://www.nationsonline.org/oneworld/map/eritrea-political-map.htm

The first recorded allusion to Eritrea was made by the Egyptians in 3000 BCE and narrates maritime commerce between the pharaohs of Egypt and local chiefs on the Red Sea coast of Eritrea (Sherman I980:4). Mussie (20II:Xx) notes that 'Eritrean history is characterized by prevalent conflicts, movements of people and external intervention'. Indeed, between the eighth and the twentieth centuries, Eritrea has successively been under the authority of Arab (Muslim) forces (eighth and fifteenth centuries), Ottoman Turks (sixteenth century), Khedival Egypt (second half of the nineteenth century), Italy (I890-I94I), Britain (I94I-I952) and Ethiopia (I962-I99I).

Eritrea emerged as a modern political entity on January I, I890 after Italy established the colony of Eritrea (Fegley I995, xxxiii). Italian colonial rule over the territory lasted until I94I. During this period, the Italians transformed Eritrea into a settler colony, introducing developments in the areas of public administration, medical service, agriculture, banking, manufacturing, light industry, road and railway system, etc. The colony experienced additional material progress after I933 as a result of Italy's war preparations against Ethiopia. Italian colonial rule over Eritrea ended in I94I, after the 
British-led Allied forces defeated the Italian army stationed in the country during the Second World War. ${ }^{8}$

In the aftermath of the Second World War, Italy was forced to renounce sovereignty over its colonies of Libya, Somaliland and Eritrea, as part of the terms of the Peace Treaty signed with the four major victorious powers (Britain, France, the United States and the Soviet Union). In relation to Eritrea, the four powers failed to agree on a 'disposal' plan as they held different views on the matter: Britain supported the partition of Eritrea between Sudan and Ethiopia; France was in favour of Italy's return as an administrative power; the US proposed a collective UN trusteeship for ten years followed by independence; while the Soviet Union preferred individual trusteeship (Iyob i995, 63).

Consequently, the fate of Eritrea was referred to the United Nations. A UN Commission, consisting of representatives from Norway, Burma, South Africa, Guatemala and Pakistan was sent to Eritrea in early I950 to prepare a report for the UN General Assembly. The Commission was to consider the views of the Eritrean population, their capacity for self-government, regional interests of peace and security in East Africa, Ethiopia's claims that Eritrea be re-joined to its 'Ethiopian motherland' and its need for an adequate access to the sea. Eventually, the Commission was divided in its recommendations: Burma, Norway and South Africa argued for a close association between Eritrea and Ethiopia; while Guatemala and Pakistan recommended full independence. On December 2, I950 the UN General Assembly adopted a resolution to federate Eritrea with imperial Ethiopia and on September II, I952 the Ethiopian Emperor Haile Selassie ratified Eritrea's constitution, thus establishing the Ethio-Eritrean federation (Iyob i995, 64).

\section{Secessionist Alienation and Armed Resistance in Eritrea}

The rights and responsibilities of Ethiopia and Eritrea within the federal framework were defined in the UN resolution. According to Fegley (I995, xxxviii),

The UN General Assembly resolution, adopted by a vote of forty-seven to ten, provided that Eritrea should be linked to the Ethiopian Empire through a loose federal structure under the sovereignty of the Ethio-

8 Subsequently, Eritrea was controlled and administered by Britain until I952. During the course of the war, the British Military Administration developed Eritrea's industrial complex to meet the needs of a war economy. 
pian emperor but with a form of internal self-government. The federal government, in the same way as the existing imperial government, was to control foreign and defence affairs, foreign and interstate commerce, transport and finance. Control over domestic affairs (including police, local administration, and local taxation to meet its own budget) was to be exercised by an elected Eritrean assembly on a parliamentary model. The Eritrean state was to have its own administrative and judicial structures and a flag.

However, during the Ethio-Eritrean federation years (I952-I962), Ethiopia set out to dismantle Eritrea's autonomous federal status through diplomatic, military and extra-legal means. Addis Ababa sabotage of the federal arrangement were attributed to its historical claim over Eritrea (Eritrea was historically part of a 'Greater Ethiopia') and pro-Ethiopian views that, 'Eritrean autonomy was infeasible and that only complete union would serve the needs of both countries'.

Therefore, during the first half of the federation period, I952-I955, 'Eritrea's façade democracy was gradually eroded by the new administration's collaboration with pro-Ethiopian members of the first [Eritrean] Assembly' (Iyob I995, 88). Emperor Haile Selassie declared the federal Ethiopian court to be the territory's final court of appeal on September 30, I952, thus placing the federal Eritrean court on a subordinate position. In July I953, Ethiopia enacted a law requiring all Eritrean males in urban areas to carry identity cards at all times, effectively restricting their mobility.

After I955, the violation of Eritrea's autonomous status within the federation became more flagrant as intimidation, coercion, and military might now came into play (Iyob I995, 89). In July I955, Tedla Beiru, the highest executive official in the Eritrean government, resigned citing 'excessive interference and pressure from the emperor's official representative in Eritrea' (Sherman I980, 27). A year later, Amharic (the language of the Ethiopian ruling elite class) was declared the official language of Eritrea, removing Tigre and Tigrinya from that position. In December I958, a bill was passed discarding the Eritrean flag and the adoption of the Ethiopian flag. A year later, the Eritrean Assembly voted to replace Eritrean laws by the Ethiopian penal code and in May I960, the Eritrean Assembly changed its name from Eritrean government to Eritrean administration.

The Ethiopian imperial regime also set out to weaken Eritrea's economy, making it dependent on Ethiopian production. To this end, Ethiopian officials discouraged foreign investment and commercial engagements in Eritrea (Mussie 20II, 62). Eritrean industries were forced to either close 
down or move their operations to Ethiopia (Keller 2007, 22). These policies had serious impact on the Eritrean working class, as 'higher rates of unemployment resulted in massive migration of Eritrean workers to the Sudan, the Middle East, and Ethiopia in search of jobs' Mussie (20II, 62).

Finally on November I4, I962, 'with a sizeable Ethiopian army surrounding the Eritrean administration building where the Assembly convened' (Iyob I995, 94), Eritrean representatives revoked Eritrea's federal autonomous status, thus turning Eritrea into Ethiopia's fourteenth province.

Ethiopia's gradual erosion of Eritrea's autonomy, which culminated in the forced incorporation of the territory in the Ethiopian empire, escalated Eritrean resistance. Organized opposition to Ethiopian domination began in earnest in the late I950 with three major movements carrying out an armed struggle over Eritrea's independence, namely: the Eritrean Liberation Movement (ELM) ${ }^{9}$, the Eritrean Liberation Front (ELF) ${ }^{10}$ and the Eritrean

9 The ELM was established in 1958 by Eritrean exiles in the Sudan. The movement sought to mobilize support inside Eritrea and abroad against the growing erosion of the federation (Negash 1997, 148). Primarily the ELM's program of action was the defense of Eritrea's autonomous status against Ethiopian encroachments (Mussie 20II, 63). Later the movement began to advocate for Eritrea's liberation by coup d'état (Iyob I995, IOI). The movement was eventually disbanded in I970 after several of its cadres deserted to an emerging movement, the Eritrean Liberation Front (ELF).

Io The ELF was founded in Cairo in July I960. The movement emphasized armed resistance as the only alternative against Ethiopian domination. Initially, the movement had no clear ideological line, espousing a combination of Islamic fundamentalism and fervent Marxism (Iyob I997, IIO). A more radical Marxist-oriented philosophy arose in the mid-I970s when young cadres returned from training camps in radical Arab countries, China and Cuba (I997, IIO). The arrival of the young cadres ignited a power struggle between the new generation and the old leadership, leading to the breakaway of the movement into three groups: the People's Liberation Front (PLF), the Eritrean Liberation Front - People's Liberation Front (ELF-PLF), and the ELF-Ubel. The ELF continued to be ripped apart by the centrifugal forces of ideology, ethnicity, religion and sectarianism while waging war against emerging nationalist groups. 
People's Liberation Front (EPLF) ${ }^{\text {II }}$. The armed struggle against Ethiopian domination evolved from occasional ambushes and hit-and-run guerrilla operations to large-scale conventional military confrontations between the Eritrean liberation movements and the Ethiopian army.

During the first decade of the conflict, the ELF resorted to rurally based guerrilla tactics due to its strategic disadvantages in open confrontations with the Ethiopian security forces. The group's attacks focused on police stations to capture Ethiopian military hardware (Shairman I980, 73), the assassination of individuals considered to oppose the revolutionary cause and acts of sabotage against vital infrastructures such as oil storage tanks, roads, railways (Pateman I990:85), and Ethiopian Airlines' planes (Sherman I98, 78). During this period, material aid for the Eritrean insurgents came from Egypt, Syria, Iraq, South Yemen and Libya (Heraclides I99I, I88).

The Ethiopian authorities attempted to counter the ELF by exploiting regional and religious rivalries between the populace (a divide and rule strategy) and attacking the ELF zones (military policy) (Pateman I990, 85). The government of Haile Selassie depended significantly upon the United States and Israel for material military support. In this regard, it has been reported that, 'from I953 to I970 the United States provided \$I47 million in military assistance to Haile Selassie's government. This amounted to almost one-half of the total US military assistance to all African countries during that time span' (Sherman I980, 75).

The second decade of the Eritrean conflict started with strong Ethiopian military and diplomatic offensive against the Eritrean secessionists precipitated by the ambush and killing of a high-ranking Ethiopian military commander (Sherman I980, 79). In late I970, a state of emergency was declared in much of Eritrea, followed by an attack against the ELF-held areas

II The EPLF emerged as a breakaway group from the ELF in September I973 under the leadership of Ramadan Mohammed Nur (General Secretary) and Isayas Aferworq (Deputy General Secretary) (Markakis I987, 64). The movement's ideological stand has been described as a 'selective, pragmatic (even eclectic), application of Marxist philosophy adapted to the particular context of Eritrea's nationalistic liberation struggle' (Iyob I995, I23). Strategically, the EPLF proved to be an effective military force attacking the Ethiopian army throughout Eritrea. The movement started out attracting large numbers of recruits, especially among the urban, intellectual and Christian youth (Figley I995, xli). Two years after its foundation it had approximately io thousand fighters in the field. Its cadres encouraged women to join the organization, and by I99I women constituted one-third of the EPLF army (Mussie 20II, 66). The movement succeeded in establishing political and military alliances with two Ethiopian movements: the Ethiopian People's Revolutionary Party (EPRP) and the Tigrean People's Liberation Front (TPLF). This cooperation played a pivotal role in defeating the Ethiopian army (Mussie 20II, 66). 
including a bombing campaign by the Ethiopian Air Force, and the implementation of forced resettlement schemes to cut off popular support to the guerrillas (Thomas 2012, 8). Furthermore, the emperor proceeded to fight the Eritreans in the diplomatic arena preventing them from getting further military aid from the Sudan, China and South Yemen (Sherman I980, 80). This offensive had the immediate effect of not only reducing Eritrean guerrilla operations but also alienating the rural population, causing resurgence in membership for the liberation movements (Thomas 20I2, 8).

The period between 1970 and I974 was marked by the fragmentation of the Eritrean liberation movements and the beginning of a civil war, fought between the ELF and the EPLF. The war ended in I974, after the Dergue ${ }^{12}$ made it an imperative for the two liberation movements to mount a united front against the new regime in Addis Ababa. Nevertheless, the Dergue persisted with Selassie's policy of Eritrea's incorporation into Ethiopia (Heraclides I99I, I82). In I976, Eritrean forces launched a massive offensive against the Dergue's troops 'amassing victory after victory, in the military arena and liberating most of Eritrea's towns' (Sherman I980, 87). By early I978, the ELF and the EPLF controlled the whole of Eritrea (Markakis I987, 63).

Eritrean military gains during this period coincided with the superpower realignment in the Horn of Africa and the Somali invasion of the Ogaden region. In I977, the US began to cut off military aid to Addis Ababa while Moscow stepped in to fill the void (Pateman I990, 88). Moreover, it has been argued that during that period, the Ethiopian government, under Soviet and Cuban patronage, directed its energies against a more serious international challenger, Somalia, turning its attention toward Eritrea once the Somali army had been driven out of Ethiopia (Pateman I990, 88). This interpretation is supported by the fact that the Ethiopian army managed to retake most of the towns held by the Eritrean secessionists six months after the Ogaden war. ${ }^{13}$

After the I978 Ethiopian offensive, the Eritrean armed struggle reached a strategic stalemate, which lasted until I984. This period saw the beginning of a new round of armed confrontations in the Eritrean civil war (I980-I98I) ending with the defeat of the ELF and ushering in EPLF hegemony (Markakis

I2 The Dergue, officially called the Provisional Military Government of Socialist Ethiopia, was the military junta that overthrew Selassie's imperial regime. It ruled Ethiopia from I974 to I987. During this period, the junta's spousal of Marxist-Leninist principles alienated the United States (Ethiopia's main external backer under Emperor Selassie), while attracting massive military support from the Soviet Union and the Eastern bloc at large.

I3 Sherman (I980, 93) notes that 'the I978 Ethiopian assault was, for most part, engineered by the Soviets and carried out by Ethiopian, Cuban and South Yemeni forces'. 
I987, 67). ${ }^{\mathrm{I}}$ The EPLF continued to gain support from the Eritrean masses and managed to mobilize the Eritreans against the Dergue. Furthermore, a weakened and demoralized Ethiopian army launched several failed attacks against the EPLF, which resulted in the build up of the Eritreans' military arsenal as they captured large amounts of arms and ammunitions from successive abortive campaigns (Tomas 20I2, I2).

The military stalemate was broken in 1984 with the EPLF moving into the offensive (Markakis I987, 68). In March I988, the balance of power shifted in favour of the Eritreans after their decisive victory at the battle of Afabet (Pateman I990, 80). Mussie (20II, 68) comments that 'the defeat of the Ethiopian army at the battle of Afabet was an immesurable military loss for Ethiopia, but it remarkably boosted the fighting morale of the liberation army'. Fierce battles continued with the EPLF collaborating with the Tigray People's Liberation Front (TPLF) and the Afar Liberation front (Pateman I990, 94).

In I990 the EPLF captured the port city of Massawa, followed by the liberation of all major towns of Eritrea (Mussie 20II). On May 24, I99I the EPLF liberated Asmara while the EPRDF took over Addis Ababa four days later (Iyob I995, 136). These events led to a regime change in Ethiopia and a de facto independence to Eritrea (Thomas 20I2, I2). Two years later a UN sponsored referendum was organized and 99.8 percent of Eritreans voted for independence (Iyob I995:I36). Eritrea was officially admitted into the community of states on 24 May 1993.

\section{Explaining the determinants of Eritrea's Successful Secession}

The central question arising from the preceding discussion concerns the factors that contributed to the success of Eritrea's struggle for independent statehood successful. This political development is quite remarkable, considering that Eritrean secessionist movements conducted their struggle amidst a number of factors that had prevented previous secessionist attempts in Katanga, Biafra and Casamance, from succeeding. These factors included scarce international recognition of their struggle, restricted supply of military

I4 After years of factional inter-Eritrean conflict, cooperation and uneasy coexistence, the Eritrean People's Liberation Front (EPLF) managed to push the ELF out of Eritrean territory into the Sudan in the early i980. 
equipment and an international consensus on the fear of the 'Balkanization' of the African continent, amongst others.

This section argues that Eritrea's successful secession is the result of a tight combination of domestic and global factors, such as Eritrea's historical and legal claims, the Dergue's policies of alienation, the effectiveness of the EPLF's strategies, the collapse of the Soviet Union and the end of the Cold War, and the role of the United States of America.

\section{Eritrea's Historical and Legal Claims}

The first factor that influenced the successful outcome of Eritrea's separation from Ethiopia relates to historical and legal considerations governing the relations between the two political entities. Eritrea had strong historical and legal foundations for its claim to independent statehood. However, Cold War politics and superpower rivalries favoured Ethiopian interests over those of Eritrea (Iyob I995, I38). This argument is in agreement with Coggins' theory of state birth, which highlights the interests of great powers and the pursuit of external security as one of the driving forces for state recognition (Coggins 20II, 449).

Haile Selassie's imperial government and the military regime that replaced it argued insistently that Eritrea was not historically a distinct entity, but part of a 'Greater Ethiopia'. The Ethiopians claimed that both entities had been part of the ancient Axumite kingdom that existed between Ioo and 940 CE. Hence, Eritrea's incorporation into the Ethiopian empire represented the reintegration of two entities that had been artificially separated by the forces of colonialism and great power politics (Sherman I980, 29).

In contrast, Eritreans insisted that Ethiopia had no historical claim over Eritrea. The Ethiopian empire had lost that right when Emperor Menelik signed a series of treaties with Italy between I886 and I889, allowing the Italians to colonize Eritrea. Menelik's actions granted a de facto recognition of Eritrea as a political entity separate from Ethiopia. Thus, Italian colonial rule brought forth 'Eritrea as a multinational state with a definite political and geographical identity’ (Sherman I980, 32).

In addition, Eritreans argued insistently that their struggle was not one of secession, but one of self-determination. Eritrea was entitled to independent statehood because its status as a former colony was consistent with the principles of the OAU (sanctity of inherited colonial borders) regarding the emergence of African states in the post-colonial era. Furthermore, the UN resolution to federate Eritrea with Ethiopia recognized Eritrea as a distinct 
political entity, with a separate constitution, a different system of government and separate executive and legislative body. The document made clear that Eritrea was not liable to annexation by Ethiopia. Hence, Emperor Selassie's abolition of the Ethio-Eritrean federal arrangement was not only an open defiance to the UN resolution but also a clear infringement of international law.

\section{The Dergue's Policies of Alienation}

Internally, the policies of the Dergue, the military regime that replaced Selassie's monarchical and feudal government, eased Eritrea's path to independence. The Dergue ruled Ethiopia between I974 and I987. During this period, the military regime implemented a series of policies that isolated it from groups inside and outside Ethiopia. The activities of these opposition movements precipitated the erosion of the Dergue, paving the way for favourable negotiated settlements on Eritrea's independence.

Upon acceding to power, the Dergue adopted 'Ethiopia First' as the motto of the Ethiopian government. Berhe $(2004$, 574) explains that, 'this ideology was oriented towards both nationalism and modernization, and was thus "directed against the weakening of the state by secessionist movements"'. Since the Dergue regarded 'Ethiopia as a monolithic society', it proceeded to declare any 'ethno-nationalist grievance or demand for self-determination as contrary to Ethiopian unity and interests' (Berhe 2004, 574).

As a result, nationalist groups demanding any form of self-determination were targeted. Thousands of Ethiopians and Eritreans were imprisoned, tortured or executed in what became known as 'the Red Terror' (Thomas 20I2, 9). The Dergue's excesses led to the emergence of many socio-political groups challenging the military government in Ethiopia, including the Western Somali Liberation Front (WSLF), the Tigray People's Liberation Front (TPLF) and the Oromo Liberation Front (OLF). The ELPF began a campaign of coalition building with these groups and their coordinated activities proved to be very decisive in the victory against the Dergue.

In addition, the Dergue's espousal of Marxism-Leninism and military cooperation with the Soviet Union made it unpopular amongst Western countries including the United States. In I976 President Carter's administration cut off military assistance to Addis Ababa evoking amongst other reasons, 'gross violations of human rights, including summary executions' and the conclusion of a \$100 million arms deal with the Soviet Union (Sherman I980, 89). In I984, the great famine intensified international scrutiny to 
the Ethiopian government's internal policies as the catastrophe coincided with the foundation of a communist party along Soviet lines followed by extravagant celebrations. According to Negash (I997, I65), 'the communist ideology pursued by the government and the war in Eritrea, which by this time had extended into the Northern region of the country, were henceforth regarded as the reasons for the famine'.

The Ethiopian government was further criticized by the international community due to the authoritarian manner in which it attempted to resettle thousands of famine stricken families to the more fertile regions of the country. Negash (I997, I65) notes that 'more than half a million people had been forcibly moved, leaving behind them thousands of people dead either on the long journeys to the homes they did not choose or in ill-prepared habitat'.

The policies of the Dergue not only created international hostility towards the government in Addis Ababa but also drove thousands of recruits into the camps of the guerrilla movements. For instance, in I989 the TPLF had grown to such an extent that the Ethiopian government considered it be a more dangerous threat than the EPLF. By I99I, the TPLF won state power in Ethiopia in the name of the Ethiopian People's Revolutionary Democratic Front (EPRDF) (Berhe 2004, 569).

\section{The Collapse of the Soviet Union and the End of Cold War}

Eritrea's attainment of statehood would have been difficult without the collapse of the Soviet Union and the consequent realignment of global politics. The fragmentation of the Soviet Union cut off guaranteed military assistance to the Ethiopian regime from the Soviet bloc, it changed the East-West framework from which the superpowers viewed developments in the Horn of Africa, and opened a new window of opportunity for the emergence of new nation-states.

From I977 to I99I the Ethiopian government depended considerably on military support from the Soviet Union and its allies. The USSR became Ethiopia's major arms supplier after Washington cut off military assistance to Addis Ababa due to human rights violations. It has been reported that by July I977 the Soviet Union had agreed to supply \$500 million worth of arms including jet fighters and missiles to the Ethiopians (Sherman I980, 90). 
Soviet hardware, Cuban military personnel and other Soviet allies sustained Ethiopia's war efforts during the last quarter of the Cold War..$^{15}$

However, the Ethiopian regime guaranteed support network began to collapse in I987 after the new leadership in Moscow warned Addis Ababa that they could not count on continuing supply of arms. Soviet authorities informed Mengistu that the Soviet-Ethiopian arms deal would not be renewed after I990. In that same year Cuban and East German troops began to withdraw from Ethiopia (Schraeder I992, I65). The collapse of the Soviet Union in I99I was followed by the capture of Asmara and Addis Ababa by the EPLF and the TPLF respectively, thus signalling the end of Mengistu's rule over Ethiopia.

In terms of global politics, the end of the Cold War led to unprecedented changes in superpower rivalries (Iyob I995, I24). During the Cold War events in the Horn of Africa and other regions of the world were analysed within the East-West framework, as means of preventing or advancing superpowers sphere of influence. However, the end of the Cold War called into question a series of Cold War rationales and the policies they generated (Schraeder I992, 57I). As a result, political developments in Eritrea began to be viewed in their own right not as an extension of East-West ideological confrontation.

Furthermore, the process of reforming the Soviet Union initiated by Mikhail Gorbachev in I986 infused 'new life into the concept of the right to self-determination' (Negash I997, I63). As pointed out by Schraeder (I992, I72), Gorbachev's policy approach towards Eastern Europe entailed 'Soviet tolerance for the fall of single-party communist states and a recognition of the need to allow the peoples of Eastern Europe to determine their own political paths independent of Soviet control'. This process called for the reassessment of the international framework governing the emergence of new sovereign states.

It was in this climate of relaxed approach to the principle of state sovereignty that Eritreans were allowed to exercise their right to self-determination. In the words of Iyob (1995, 138) 'the demand of the Eritrean people for self-determination was no longer seen as an isolated case viewed as a dangerous precedent, but one of many cases'.

\footnotetext{
I5 As previously mentioned, Soviet military assistance was instrumental in ensuring Ethiopia's victory over the Somali army during the invasion of the Ogaden region, the re-conquest of Eritrea from the Eritrean liberation movements in the offensives of 1978, and in subsequent assaults aimed at crushing guerrilla insurgencies in Eritrea and Ethiopia.
} 


\section{The Role of the United States of America}

The United States' efforts to find a diplomatic solution to the civil war in Ethiopia in the late I980s contributed resolutely for Eritrea's successful secession. In this regard, Paquin (2010, I28) notes that the fate of Eritrea had always been linked to the geostrategic interests of the United States of America (US). From I952 to I99I successive administrations in Washington DC consistently opposed Eritrea's independence on the basis of maintaining stability in the Horn of Africa. In I99I the Bush administration reversed this policy after Assistant Secretary for African Affairs Herman Cohen declared US support for a UN-supervised referendum on Eritrean independence (Schraeder I992, 570).

Starting in I989, various third parties including Italy and the US attempted to broker peace deals between Eritrea and Ethiopia and between Ethiopia and various opposition movements operating inside the country (Keller 2007, 24). The US engaged on a number of official and un-official talks with Ethiopian and Eritrean leaders, including the failed mediation efforts conducted by former President Jimmy Carter in I989 (Paquin 2010, 139). The US intensified its level of involvement after Mengistu's departure from power on May 2I, I99I. The Assistant Secretary of State for African Affairs Herman Cohen was sent to London to mediate between the insurgents and the collapsing Ethiopian government.

According to Schraeder (1992, 570) 'the net result of US involvement was a significant contribution to a transfer of power, which largely avoided the bloodshed and clan conflict still evident in Somalia'. As part of the Agreements, the US authorized the TPLF to takeover Addis Ababa and to establish a broad coalition government there. Moreover, the US also declared its support for a referendum on Eritrea's independence after a two-year transitional period.

American support for a referendum on Eritrea's independence was a political tool to stop the civil war and promote stability in both Ethiopia and Eritrea (Paquin 20I0, I40). In the author's own words: 'a denial of Eritrea's right to secede may have caused war to resume in Ethiopia'. American officials also requested the EPLF leadership not to issue a unilateral declaration of independence after they captured Asmara in I99I because it would further destabilize Ethiopia. The US argued that both the new Ethiopian and Eritrean government needed to consolidate their power to facilitate a stable transition to Eritrea's independence.

Finally, the US affirmed Eritrea's right to self-determination without the previous consent of the OAU, leaving 'the organization with very little 
option but to back this policy' (Paquin 20IO, I4I). This resonates with Coggins (20II, 449) observations that when a Great Power (in this case the United States) confers legitimacy upon a secessionist movement/state its decision initiates a cascade of legitimacy throughout the remaining members of the international system.

\section{The Strategies of the Eritrean People's Liberation Front}

The success of Eritrea's struggle for statehood was also facilitated by the military defeat of the Ethiopian regime. The defeat of the Dergue can be attributed to a number of factors including the military and diplomatic tactics of the Eritrean liberation movements. Special attention must be paid to the strategies of the EPLF, as it was the sole movement to engage the Ethiopian government in the last and decisive decade of the armed struggle. The fight against Ethiopian occupation was fought on two fronts: through military campaigns against the Ethiopian army and through diplomatic endeavours aiming at explaining the reasons for Eritrea's independence.

On the military front, the EPLF adopted a number of strategies that proved effective. Firstly, the EPLF counteracted the military superiority of the Ethiopian army by adhering to the practices of guerrilla tactics and protracted warfare (Thomas 20I2, I). Secondly, the EPLF secured massive popular support to the struggle by adopting a number of social reforms in the territories under its control such as land ownership, health, education and gender relations (Sherman I980, I0I-I06). Thirdly, the EPLF relied primarily on Ethiopia as source of arms and equipment capturing it on the battlefield and in guerrilla raids on specific targets (Keller 2007, 24). Fourthly, the EPLF put in practice a policy of self-reliance in the liberated zones, setting up industries to manufacture and repair medicines, clothes, vehicles, arms and military equipment. Lastly, the EPLF established alliances with other groups within Ethiopia opposing the Dergue's regime, such as the TPLF and the OLF.

It is worth noting that, in the late I980's, the various dissident groups fighting the Ethiopian government united under one organization umbrella called the Ethiopian People's Revolutionary Democratic Front (EPRDF). As stated by Iyob (I995, I34) the EPLF's alliance with the EPRDF 'was based on the latter's recognition of the Eritrean demand for self-determination and a mutual conviction of the need to rid Ethiopia of the Mengistu regime'. Both the EPLF and the EPRDF coordinated their offensives against the Ethiopian forces. The EPLF focused on the capture of Asmara, while the EPRDF relied on EPLF logistical support for the capture of Addis Ababa. Eventually the two fronts defeated the Ethiopian army becoming the main participants in 
the US-led ceasefire negotiations in London. In I993, Eritrea became independent with the full blessing of the EPRDF government in Addis Ababa.

The fight was equally effective on the diplomatic front. The EPLF embarked on a policy of winning over international public opinion to the cause of the Eritrean people. To this end three main strategies were implemented: firstly, the EPLF reframed the nature of its armed struggle from anti-colonial war to a war for the exercise of the right to self-determination (Negash I997:I63); secondly, the EPLF issued a referendum document stating that Eritreans should be given the option to choose from one of the three alternatives: a) union; b) federation within a regional autonomy framework; or, c) independence; thirdly, the EPLF sought African support for Eritrean self-determination pointing to parallelisms between Eritrea and the historical and legal arguments used the to justify the cases for Namibia and Western Sahara's independence.

The strategy emphasizing the right to self-determination as the primary cause of the war garnered enormous support in Europe and North America. Although, in its proposal the EPLF attributed supervisory role to the OAU and the UN implementation of the referendum option the Ethiopian government dismissed it. The EPLF's proposal was seen as evidence that the movement was trying to find a political solution to the conflict (Negash I997, I64).

\section{Conclusion}

In the course of roughly a century, Eritrea experienced massive political transformations. It was established as an Italian colony (I890-I94I), administered by Great Britain (I94I-I952), federated and incorporated into Ethiopia (I952-I962), fought for independence (I962-I99I), eventually acceding to independent statehood (I993). This study examined the dynamics of secession and the determining factors behind Eritrea's successful accession to independent statehood.

Eritrean sense of a distinct national identity emerged during the decades of Italian colonial rule, intensified during the years of British administration, maturing as a result of the experiences of oppressive Ethiopian imperialism. A series of socio-political and economic grievances against Addis Ababa's systematic dismantlement of Eritrea's federal status led to the rise of secessionist movements in Eritrea and the beginning of nearly three decades of armed conflict, which ended with the defeat of the Ethiopian army. This 
last event paved the way for a UN-sanctioned and monitored referendum on Eritrean independence and the territory's accession to statehood.

Since the armed struggle for Eritrea's independence was conducted amidst a number of factors that had prevented previous secessionist attempts from succeeding, this study has argued that Eritrea's successful secession was the result of a tight combination of both domestic and external factors. Domestically, the Ethiopian army was defeated as a result of the Dergue's policies of alienation and the effectiveness of the strategies of the EPLF. Externally, Eritrea's historical and legal claims to sovereignty, the end of the Cold War and the collapse of the Soviet Union as well as the mediating role of the United States were decisive in ensuring Eritrea's recognition as an independent state on 24 May I993.

\section{REFERENCES}

Anderson, G. 2013. Secession in International Law and Relations: What Are We Talking About?, Available at: http://digitalcommons.lmu.edu/ ilr/vol35/iss3/I.

Bamfo, N. 20I2. 'The Menace of Secession in Africa and Why Governments Should Care: The Disparate Cases of Katanga, Biafra, South Sudan, and Azawad', Global Journal of Human Social Science Sociology Economics \& Political Science I2 (I0): 37-48.

Berhe, A. 2004. 'The Origins of the Tigray People's Liberation Front', African Affairs. I03 (413): 569-592.

Breary, B. 2008. 'Separatist Movements: Should Nations have a Right to Self-determination?', CQ Global Researcher. 2 (4): 27-57.

Buchanan, A. I99I. Secession: the morality of political divorce from Fort Sumter to Lithuania and Quebec. Colorado: Westview Press.

Butt, A. I. 20I7. Secession and Security: Explaining State Strategy Against Separatists. New York: Cornell University Press.

Coggins, B. 20II. 'Friends in High Places: International Politics and the Emergence of States from Secessionism', International Organization. 65 (I): 433-67.

Dersso, S. 2012. 'International Law and the Self-determination of South Sudan'. Institute for Security Studies. Paper 23I. 
Doyle, D. H. (ed) 20Io. Secession as an International Phenomenon: from America's Civil to Contemporary Separatist Movements. Georgia: University of Georgia Press.

Engelbert, P. et al. 2002. 'Dismemberment and Suffocation: A Contribution to the Debate on African Boundaries', Comparative Political Studies. 35(10): I093-III8.

Fegley, R. 1995. Eritrea. Colorado: Clio Press.

Herbst, J. I989. 'The Creation and Maintenance of National Boundaries in Africa', International Organization. 43 (4): 673-692.

Heraclides, A. I99I. The Self-determination of Minorities in International Politics. London: Frank Cass.

Horowitz, D.L. I985. Ethnic Groups in Conflict. Los Angeles: University of California.

Hughes, A. 2004. 'Decolonizing Africa: Colonial Boundaries and the Crisis of the (Non) Nation State', Diplomacy \& Statecraft. I5(4): 833-866.

Iyob, R. I995. The Eritrean Struggle for Independence: Domination, resistance, nationalism 1941-1993. Cambridge: Cambridge University Press.

Ker-Lindsay, J. 2012. The Foreign Policy of counter Secession: Preventing the Recognition of Contested States. Oxford: Oxford University Press.

Keller, E. 2007. 'Secessionism in Africa', The Jornal of African Policies. I3(I): I-26.

Kohen, M.G. (ed) 2006. Secession: International Law Perspectives. Cambridge: Cambridge University Press.

Markakis, J. I987. 'The Nationalist Revolution in Eritrea', The Journal of Modern African Studies. 26 (I): 5I-70.

McNamee, T. 2012. The first crack in Africa's map? Secession and Self-Determination after South Sudan. The Brentehurst Foundation. Discussion Paper 20I2/OI.

Mussie, T.G. 20II. Eritrea. California: Greewood Publishing Group.

Negash, T. I997. Eritrea and Ethiopia: The Federal Experience. Uppsala: Nordiska Afrikainstitutet.

Paquin, J. 20I0. A Stability-Seeking Power: U.S. Foreign Policy and Secessionist Conflicts. Quebec: McGill-Queen's University Press.

Pateman, R. I990. 'The Eritrean War'. Armed Forces Q Society. I7 (I): 8I-98.

Pavkovi , A \& Radan, P (eds) 20II. The Ashgate Research Companion to Secession. Farnham: Ashgate Publishing Company. 
2007. Creating New States: Theory and Practice of Secession. Hampshire: Ashgate Publishing Limited.

Premdas, R. 2013. Secession in the Contemporary World. Available at: http://www.isa-sociology.org/publ/E-symposium/E-symposium-vol-3-2-2013/EBul-Premdas-Jul2or2.pdf

Schraeder, P.J. I992. 'The Horn of Africa: US Foreign Policy in an Altered Cold War Environment', Middle East Journal. 46 (4): 57I-593.

Sherman, R. 1980. Eritrea: The Unfinished Revolution. New York: Praeger.

Thomas, C. 2012. 'The Road to Afabet: The EPLF, Protracted Warfare, and the Liberation of Eritrea' in Brazilian Army Command (eds). Acta of the XXXVII International Congress of Military History, Decolonization, Colonial, and Independence Wars from the 18th Century to the Present. Rio de Janeiro: ECEME Press.

Troco, A. A. 20I8. 'Determinants of Successful Secessions in Post-colonial Africa: The Case of South Sudan', Brazilian Journal of African Studies. 3 (6): 55-74.

Ylonen, A. 2013. 'The State and the 'Southern problem' in Sudan: Marginalisation, self-determination and secessionism', in Ndlovu-Gatsheni, S \& Mhlanga, B. The Bondage of Boundaries and identity Politics in Postcolonial Africa: The 'Northern Problem' and Ethno-Futures, Pretoria: Africa Institute of South Africa.

Wood, J.R. I98I. 'Secession: A Comparative Analytical framework', Canadian Journal of Political Science. I4 (I): I07-I34. 


\begin{abstract}
Contrary to the vast majority of African states that gained independence through processes of decolonization from European colonial powers, Eritrea attained independent statehood by formally withdrawing from an established sovereign African state. This occurrence represents a remarkable political development in post-colonial Africa for at least two reasons: I) it was the first time that a secessionist movement succeed in its quest for independence; 2) the struggle for independence took place within a continental framework that was particularly hostile to the emergence of new states. Drawing upon secondary qualitative data sources, this study examines Eritrea's secession against the background of scholarship that emphasizes the social, political and economic context in which secessionist struggles take place. It argues that Eritrea's successful secession lies at the intersection of domestic and global politics, combining factors such as the region's historical and legal claims for territorial selfdetermination, the policies of alienation of the parent-state, the effectiveness of the strategies of the secessionist movements, the end of the Cold War and the supportive role of the victorious superpower. The study adds new and systematic contributions to the debate on the determinants of successful secessions in post-colonial Africa.
\end{abstract}

\title{
KEYWORDS
}

Eritrea; Self-determination; Secessionist Movements; Secessionist Conflicts; Postcolonial Africa.

Received on February 24th, 2019 Accepted on August 3rd, 2019 